\title{
The Nexus of Macroeconomic Policy, Investment and Economic Growth in Nigeria
}

\author{
Udo N. Ekpo \\ Department of Economics, Faculty of Social and Management Sciences, Akwa Ibom State University, Obio \\ Akpa Campus, Akwa Ibom State, Nigeria. \\ udonekpo@yahoo.com
}

\begin{abstract}
This paper examined the nexus of macroeconomic policy (monetary and fiscal policies), investment and economic growth. The findings established that monetary and fiscal policies affect aggregate investment and economic growth in Nigeria. It also showed that the management of monetary and fiscal policies in Nigeria has not yet achieved macroeconomic stability objective. The implementation of the monetary policy, in particular, has not helped to stimulate savings and ensure it's efficient allocation for investment purposes, hence appropriate rate of investment and sustained economic growth has eluded the country. For a sustainable macroeconomic policy that will engender appropriate rate of investment and sustained economic growth, this paper therefore, recommends harmonious working relationship between monetary and fiscal authorities, effective coordination and harmonization of monetary and fiscal policies, monetary policies should focus on lowering interest rates and increasing availability of credits to productive sectors of the economy. Furthermore, the monetary authorities should strongly discourage exploitative tendencies and unethical practices of banks, banks should avoid sharp and unscrupulous practices and discipline themselves to play according to the rules of the game as well as effectively carry out their financial intermediation role.
\end{abstract}

\section{Introduction}

One of the fundamental macroeconomic objectives of a country is the attainment of accelerated and sustained economic growth and development in the economy. This objective, among other, is to be achieved through the creation of a conducive economic environment by the government. Conducive economic environment could be created when the government formulates and implements appropriate, effective and sound macroeconomic policies and programmers which, among other things, facilitate the availability of required resources, stimulate saving and investment, and ensure macroeconomic stability (low inflation rate, exchange rate stability and low interest rate) in the economy.

Investment, the accumulation of real capital goods (i.e. productive assets which yield a future flow of goods and services), is widely acknowledged by economists as an important ingredient in the growth and development process of a country. Yolopoulest and Nuggets (1976) asserted that the rate of investment in a nation is a critical factor in the economic growth/development of that nation. Scott (1991) cited by Soludo (1998) posited that the keyword for economic growth and development is investment. He stressed the crucial role of investment in economic growth thus: "economic growth is proximately caused by only two things material investment and the growth of quality-adjusted employment, which includes the effects of human capital". In the same vein, Bamidele and Englama (1998) also emphasized the role of investment in economic growth of a country by asserting that without prejudice to the importance role of natural resources, good climate, socio-cultural and political factors, economic growth comes about through the building-up of a large stock of productive assets and skills.

Investment decision and activities are greatly influenced by government policy. Dornbusch and Fischer (1981) asserted that investment is significantly affected by both monetary and fiscal policies. Thus, investment (and economic growth) is affected by macroeconomic policy. Macroeconomic policy encapsulates economic measures adopted by the government in the management of the economy which are directed at influencing macroeconomic variables to achieve certain goals. In macroeconomic management the principal macroeconomic policies often used are monetary and fiscal policies. Other complementary policies include exchange rate policy, commercial/trade policy, income policy, debt management policy, interventionists and institutional reform policies.

Despite the crucial role of capital accumulation in economic growth, there has been limited amount of capital investment in Nigeria due to prevalence unconducive economic environment created by poor performance of macroeconomic policies. The amount of capital investment in any country depends on investment productivity, which is directly related to the yield or desirable expected return on investment. The expected return on investment in Nigeria has been made undesirable due to persistent macroeconomic instability, infrastructure shortages, corruption, among other things. Except for few years, there had been double 
digits inflation rate, high lending rates, low saving deposit rates and high foreign exchange rates. For instance, inflation rate rose to the peak of $72.8 \%$ in 1995 before declining to $18.9 \%$ in 2001 and $20.2 \%$ in 2005 . The maximum leading rate was $36.09 \%$ in 1993 and $30.19 \%$ in 2002. The exchange rate increased from N0.98 to US $\$ 1$ in 1986 to $\$ 133.50$ to US \$1 in 2004. Basic infrastructures are in short supply in the country. For example, the road networks in the country had been in various stages of disrepair. Electricity supply, for many years, had been in deplorable state with power outages, rationing and load shedding becoming very frequent thereby compelling electricity users (households, business firms and government establishments) into private electricity production by installing their individual's electric power generating units at a very high cost to provide their own electricity in part or in whole.

This study was initiated to examine the nexus of macroeconomic policies (particularly monetary and fiscal policies), investment profile and economic growth in Nigeria with the aim of proffering a sustainable macroeconomic policy that would engender appropriate rate of investment and sustained growth. The rest of the paper is organized as follows: Section 2 presents the conceptual framework and empirical evidences. Nigeria's macroeconomic policies performance is examined in section 3. In section 4 there is Nigeria's aggregate investment and economic growth rate. Section 5 concludes the paper.

\section{Conceptual Framework}

Measured by the percentage change in per capita real income or output, economic growth occurs in an economy when there is a sustained annual increase in the amount of real goods and services produced for it's citizen's consumption and investment. Kindlebeger (1965) stressed that economic growth involves not only more output derived from greater amounts of inputs but also greater efficiency (that is an increase in output per unit of input). The quantity of goods and services produced in the country depends on the productive capacity of the economy. Hence, economic growth can also be described in terms of the expansion of a nation's productive capacity. The productive capacity of an economy depends basically on the quantity and quality of it's resources as well as its level of technological attainment. Thus, it entails expanding the quantity and improving the quality of a country's resources as well as its level of technology to produce more goods and services for its people. It involves increase in the economy's potential for production as well as the ability to utilize the expanded productive capacity efficiently. Economic growth, therefore, can be described as a sustained quantitative increase is country's per capita output (or income) accompanied by expansion in it's labour force, consumption, volume of trade and increase in level of technology (Peterson, 1978).

Investment is that part of national income or expenditure expended on the acquisition of real capital goods. Generally conceptualized in terms of capital formation (that is increase in capital stock), investment is the process of incremental change in capital stock whereby economic agents (individuals, firms and government) set asides part of it's resources to create material and human capital so as to enhance future stream of earnings, increases productivity and efficiency, and improve the living standard of the people (Fakiyesi, 1998). It is an addition to the stock of capital goods in existence. Symbolically, investment in a given period, can be represented as

$$
I_{t}=K_{t}-K_{t-1}
$$

Where $I_{t}=$ Investment in the current period.

$\mathrm{K}_{\mathrm{t}}=$ Capital stock at the end of the current period

$\mathrm{K}_{\mathrm{t}-1}=$ Capital stock existing at the end of last period

Investment involves accumulation of real capital goods (i.e. productive assets) such as the establishment of plants, acquisition of machinery, equipment and tools, provision of qualitative education and adequate health care facilities, construction of new factory, houses, public works like dams, roads, and buildings. It is the means by which changes in the real capital stock of a nation are brought about thereby adding to the country's productive capacity.

Investment expenditure is categorized into gross and net investment. While gross investment is the total investment expenditure expended by economic agents or economy on new capital goods in a year, net investment is gross investment minus replacement investment. Replacement investment is investment made for replacement of capital goods lost due to wear, tear and obsolescence. Net investment is, therefore, the actual addition to existing capital stock in a year. Hence productive assets of a country increases (and by implication the productive capacity of the economy expands) when gross investment exceeds replacement investment. According to Oshikoya (1994), in Africa, the minimum investment needed to replace depreciated capital is estimated at $13 \%$ of GDP.

In an economy, the government and the firms are two major economic agents that are involved in investment. Domestic investment, therefore, comprises private and public investment. Private investment, which can as well be categorized into domestic private investment and foreign direct investment, is investment in physical capitals. It deals with investment by firms. According to Soludo (1998), private investment is classified into business fixed capital goods like new machinery and equipments, new factories and offices, investing in 
new techniques and product with the aim of improving the quality of the firm output; and working capital such as stock of raw materials, cash and inventories. Public investment, on the other hand, is investment undertaken by the government. It includes all investments in the provision of social and economic "Overhead Capital" which Development Economists denote as infrastructure. It constitutes capital stock and services which could be considered as basic inputs requirement for proper functioning of economy; without which primary, secondary and tertiary production activities cannot function effectively. In it's widest sense, it includes all public services from law and order through education and public health to roads, railways, communication, electricity supply and water supply as well as such agricultural overhead capital as irrigation and drainage systems (Jerome, 1999).

Macroeconomic policy involves the use of a number of policy instruments over time to manipulate or systematically control key economic aggregates such as national income, employment, general price level and the balance of payments, for the purpose of combating pressing economic problems of the society and achieving broad microeconomic and macroeconomic objectives. The macroeconomic problems which macroeconomic policy is set to tackle are unemployment, price instability, low rate of economic growth, income inequality and balance of payment deficit. The long-run goals of macroeconomic policy, therefore, include full employment (low level of unemployment), reasonable price stability, sustained economic growth, balance of payment equilibrium otherwise referred to as internal and external balance. Ekpo (2003) posits that in developing countries, Nigeria inclusive, other important macroeconomic goals include proper and efficient debt management, equitable distribution of income, elimination of economic dualism (promotion of rural development and provision of basic needs (food, shelter, clothing, and education)). These are economic indicators upon which investor's confidence, expectations and decisions on whether to invest or not are based. These macroeconomic variables could as well be regarded as the economic fundamentals or preconditions that must be fulfilled without which investment may not take place and economic growth will elude a country.

This study is particularly interested in monetary and fiscal policies.Monetary policy is a package of actions designed to influence the level and growth of money supply as well as the cost of credit (that is interest rate) in the economy in line with the expected level of economic activity to attain macroeconomic goals of growth and development (Oresotu, 1993; Bamidele and Englama, 1998) On the other hand, fiscal policy is the discretionary changes in the level, composition and timing of government expenditure and taxation.

\section{Empirical Evidences}

In the theories of economic growth (and development), it has been demonstrated that economic growth is absolutely necessary if the economy is to avoid a growing volume of unemployment of both labour and other economic resources. A major determinant of the level, structure and rate of economic growth, in any economy, is investment. (capital formation). Investment determines the rate of accumulation of physical capital, hence is a crucial ingredient in the growth of productive capacity of the economy. In addition to increasing the productive capacity of the economy through addition to capital stock, investment raises the income of the people, boosts the aggregate demand in the economy and consequently, engenders economic growth. In the long-run, investment helps to increase productivity and competitiveness of a country. Studies on the relationship between investment and economic growth show that there exists a strong correlation between them (Ahuja, 2011). By implication, high rate of growth is likely to be achieved in economies which employ large portion of GDP in investment while low growth rate are experienced in countries which allocate small part of their GDP to investment.

Economic growth models support the important role of investment in economic growth. They accept that the rate of growth of the economy is determined by the accumulation of physical capital and human capital, the efficiency of resources use and the ability to acquire and apply modern technology (Soludo, 1998). While the old growth theories emphasis is on investment in physical capital only; the endogenous (new) growth models enlarge the scope to include physical capital; human capital, intangible capital such as knowledge and other things that yield quality enhancements to inputs and output from within the system. Harrod-Domar model, based on classical theory, gives premium to physical capital stock (investment) as engine of economic growth. It stresses that GDP growth is proportional to the share of investment spending in GDP. The conventional "neoclassical" growth theory as modeled by Solow (1956) holds the view that growth takes place as a result of the accumulation of physical capital and expansion of the labour force, in conjunction with "exogenous" factor, technological progress that makes physical capital and labour more productive. To them government policy can not affect economic growth except temporarily during the transition of economies to their steady state. In the new (endogenous) growth theory (Romer, 1990; Lucas, 1988), what causes economic growth in both the shortrun and long-run are not exogenous factors, but "endogenous" ones, which are assumed to be related to the knowledge and behaviour of the people responsible for the accumulation for physical capital. Jhingan (2010) posits that the new growth models emphasis technical progress which takes place as a result of the rate of investment, the size of capital stock and the stock of human capital. Asides incorporating human capital as an 
endogenous part of the growth ingredients, the new growth theory provides room for the role of other factors, particularly the effect of government policy, in explaining the growth process. .

In developed and developing economies, Nigeria inclusive, empirical studies have shown significant contribution of different types/categories of investment to economic growth (Aschauer, 1989; Stightz, 1996; Iyoha, 1998; Bamidele and Englama, 1998; Obaseki and Onwiduokit, 1998). While private investment is widely regarded as engine of "economic growth", public investment especially investment in infrastructure is described as "growth inducing" investment. It has also been established that it is all investments that matters for growth. Physical investment (whether public investment in infrastructure or private investment by firms) adds to the stock of physical capital. Investment in education and research and development (R\&D) accumulates into a stock of human capital. The different types of investment are symbiotic with one reinforcing the other.

Stightz (1996) carried out a study based on case studies, econometric data and economic theory to investigate the policies and other factors which contributes to rapid growth of eight East Asian economies often referred to as the "East Assian Miracles". He asserted that investment in physical capital, human capital and infrastructure (both physical and institutional) help to increase the rate of return on private investment and thereby promote growth. Oshikoya et al (2002) viewed public infrastructure as the "wheels" of economic activity since it's availability provides conducive environment for productive activities to take place and facilitates the generation of economic growth in a country. Thus, economic growth is positively or negatively impacted by the character and state of a country's infrastructure.

Aschauer (1989) asserted that the stock of public infrastructure capital is indeed a significant determinant of total factor productivity growth. He examines the impact of public investment in infrastructure on economic growth by estimating aggregate production function using US time series data. The results revealed a striking relationship between the US productivity slowdown and the decline in the rate of growth of public capital stock. It shows large contribution of public infrastructure to output which was between two to five times as high as for private investments capital, and that the accumulation of public capital has a sizeable positive effect on private investment. This suggests that an aggressive and appropriate public investment strategy in infrastructure can enhance private investment and facilitates economic growth.

Ekpo (1999) examined the relationship between public expenditures and economic growth via links with private investment in Nigeria. The result of that study shows that government expenditures on infrastructure complement and stimulate private initiatives, in aggregate terms public sector investment crowdsin private investment. He maintains that the quality of government investment is important for ensuring the efficiency of the private sector.

Following from the above, aggregate investment in the economy is greatly influenced by macroeconomic policy of the government. The theories of investment as shown in the works of Dailamu and Walton (1989) and Green and Villanueva (1991) also demonstrate that investment is significantly affected by macroeconomic policy. They asserted that investment (particularly private investment) is affected by such factors as macroeconomic instability, macroeconomic policy (monetary, fiscal and exchange rate), uncertainty and irreversibility, and credibility of policy reform. It has been observed that macroeconomic policies adjudged to be consistent and good by potential investors have a stimulating effect on investment because they facilitate long-term planning investment decision and activities, and encourage private capital accumulation (Hadjimicheal et al, 1995). Good and coherent macroeconomic policies are those policies that facilitate improvement in saving, buoyant local business climate (including tax policies), low cost of production in countries competing for foreign investment, availability of high skill labour and high quality infrastructure. The absence of a coherent macroeconomic policy creates an atmosphere of uncertainty in the economy which forces economic agents to "postpone" investment and, thus reduce the level of investment and economic growth.

Monetary and fiscal policies instruments affect investment and economic growth indirectly through their effects on macroeconomic variables. Such macroeconomic policy variables as shown in empirical studies including that of Fisher (1993) include the rate of inflation, exchange rate, interest rate, budget deficit, money supply (narrow money, $\mathrm{M}_{1}$ and broad money, $\mathrm{M}_{2}$ ), public expenditure and receipts (taxation), public debt (domestic and external debts), debt service ratio and credits to the economy (credits to private and public sectors). These variables strongly affect the rate of saving and investment and, consequently economic growth. For instance, Mckinnon (1973) has shown that interest rate determines investment. The rate of interest affects both the willingness to save and the demand for investment. Agu (1988) examined the determinants and structure of real interest rate in Nigeria between 1970- 1985 and found a negative effect of low real interest rate on saving and investment. In developing countries, Nigeria inclusive, a high rate of inflation has been found to have negative impact on investment, especially, private investment (Oshikoya, 1994). The consequences of budget deficit depend on how the deficit is financed and what the deficit is spent on (Ekpo et al, 2011). However, excessive reliance on any of the financing methods has it's own dangers and is likely to affect macroeconomic stability. According to Easterly and Hebbel (1997) public deficit financing can be through money financing, domestic debt financing and external debt financing. Money creation leads to high inflation 
rate which has been found to be inimical to private investment in developing countries including Nigeria. Domestic borrowing crowds-out private investment through high interest rate and reduction in loanable fund available for private sector to borrow. External borrowing may results in current account deficit and real exchange rate appreciation, balance of payment crisis or external debt crisis.

High external debt stock and debt servicing burden have dampening effect on investment. The existence of high external debt and debt service burden affect investment mainly through the "debt overhang effect, the crowding out effect and credit rationing (Iyoha, 1997; Greene and Villanueva, 1991). The debt overhang effect refers to a situation in which a high debt burden discourages private investment since the accumulated debt stock is view as a tax on future income and production. In the case of "crowding-out" effect, high external debt results in a situation where the resource which could have been used for investment in a country is diverted to service foreign debt. Credit rationing refers to a situation in which high indebted country find it difficult to obtain loan in international capital markets and this lead to reduction in investment.

Reduction in economic instability, stimulation of employment and income and output, and long-term economic growth could be achieved through variation in government spending and taxes. Depending on what the government wants to achieved, time-to-time variation in government spending could produce stimulating or restraining effects on economic activities. Taxes reduction helps to stimulate the economy while taxes increase produces restraining effects. For example, reduction in taxes leaves more money in the hands of the people and businesses for consumption and saving. As consumption and saving increased, investment and output of the economy expand leading to more employment and income, and eventually economic growth.

In Nigeria, especially from the late 1980s through 1990s, low level of investment and investment uncertainty experienced are attributed to high and unpredictable inflation and price variability, uncertain demand, fluctuating real output; exchange rate variability; interest rate volatility; foreign debt burden; macroeconomic instability arising from external shocks, incomplete credibility of policy reform, and sociopolitical instability, in addition to traditional determinants of investment. Iyoha (1998), using data for the 197094 period to study the determinants of aggregate investment in Nigeria, found that foreign exchange premium, external debt-to-income ratio, inflation rate, output volatility and uncertainty, and increase in uncertainty and external debt have undoubtedly played a critical role in depressing investment in Nigeria.

\section{Macroeconomic Policy Performance in Nigeria (1970-2006)}

Monetary Policy: Monetary policy is concerned with the availability, cost and direction of credit in the economy. It involves changing the volume of money supply (increasing or decreasing) from time to time with the expectation that such changes will influence total spending and aggregate demand in the economy thereby promote stable prices, stimulate investment, output and employment and support the external equilibrium. The primary objectives of monetary policy is to ensure that over time, the expansion in money and credit will be adequate for the long-term need for the growing economy at stable prices. However, in the short run, other objectives include combating inflationary pressures, restoring and sustaining balance of payments, maintaining a stable exchange rate at internationally competitive level and ensuring stability in the money market. Monetary policy also aimed at removing obstacles to the growth of savings and it's efficient allocation for investment. The decisions on the size of national credit and it's distribution between the public and private sectors are made through monetary policy. Nigeria's monetary policy objectives include achievement of domestic price and exchange rate stability, maintenance of healthy balance of payments position, development of a sound financial system and, promotion of rapid and sustainable rate of economic growth and development (Sanusi, 2001).

Oyejide (2002) posited that monetary policy strategies are basically of three types - monetary targeting, exchange-rate targeting and inflation targeting. Nigeria's monetary policy has been anchored on a monetary targeting framework and price stability (Nnanna, 2002). Nnanna further maintained that in line with global development, more emphasis is placed on price stability because other objectives of economic policy are easily derived from the maintenance of macroeconomic stability and also due to empirical evidence and general consensus that domestic price volatility undermines the value of money as a store of value and frustrates investment and growth. Monetary targeting involves targeting money supply. During the regulated regime, narrow money $\left(\mathrm{M}_{1}\right)$ was the measure of money supply of primary concern while in the deregulation period, broad money $\left(\mathrm{M}_{2}\right)$ constitutes the primary focus. Since monetary policy actions influence the economy through both availability of credit and its price (interest rate), the task of monetary authorities in Nigeria had been to ensure adequate liquidity at an optimum cost by influencing interest rates appropriately, and this is in line with government's objective of macroeconomic stability which is a precondition for investment, growth and development.

In Nigeria, two regimes of monetary policy - the direct (non-market) approach and indirect (market) approach have so far been implemented. The direct approach to monetary control involves the fixing of quantitative ceiling on bank credits expansion, administratively fixing of interest rate and taking actions to ensure banks compliance while the indirect approach involves the use of market based instruments to effect 
changes in the availability and cost of credit (Oresotu, 1991). Between 1960 and 1986, Nigeria relied on the direct control regime using instruments such as cash reserve requirement, selective credit controls, fixing of credit ceilings, imposition of special deposits, direct regulation of exchange rate and interest rates to control key monetary aggregates. The choice of direct control was predicated on Nigeria's underdeveloped financial market and the expanding public sector role as a result of increased revenue from the oil sector. There was also need to administratively managed interest rates, credit ceiling and exchange rate so as to influence the growth of domestic credit in the economy as well as ensure that credit is made available to productive sectors of the economy at lower interest rate to enhance economic growth. The 'preferred' sectors, about 18 in number in the early 1970s and reduced to about 4 in 1986 included agriculture, manufacturing, real estate and construction, mining and quarrying, transport and communication. The interest rate charged on the 'preferred' sectors was lower than the market rate and the credit ceiling of banks to the 'preferred' sectors was fixed at $30-40 \%$ of the total loans and advances in the early 1980s but later reduced to $7 \%$ in 1985 .

During the control regime period, especially up to 1982, greater percentage of credit to the economy went to productive sector. For instance, as shown in Table 1, in 1980, 1981 and 1982, credits to private sector were about $66.7 \%, 59.7 \%$ and $52.1 \%$ respectively. The flow of credit in the economy had a positive influence on investment, output and domestic price level then. However, in general, monetary management under non-market based regime was inefficient and had many drawbacks. Government controls on nominal interest rates, credit ceiling and exchange rates was counterproductive. It resulted in distortion in prices and monetary instabilities. The administered low interest rate policy in the presence of high inflation rates created an environment of "financial repression". Financial repression refers to the difference between interest rates and inflation rates. It heightened demand for cheap credit, inhibited saving and stimulated current consumption, make banking industry less competitive and inefficient in mobilization and distribution of financial resources, produced a damaging scope for corruption, encouraged inefficient investment and unproductive or non-performing loan.

Following the deregulation of the Nigerian economy and subsequent introduction of a market driven policy, the Structural Adjustment Programme (SAP) in July, 1986 with the aim of reducing the average deficit/GDP ratio to $3.0 \%$ in the short-run, eliminating prices distortion, reduce public sector role, promote nonoil sector and eventually achieve fiscal balance, there was a shift to the indirect monetary control (market-based) approach. This approach involves the use of market-based instruments like reserve requirements, discount rate, and open market operations (OMO) to effect a change in the availability and cost of credit in the economy. Other measures adopted included prudent guidelines, reintroduction of stabilization securities, improvement of the regulatory environment, upward review of the minimum paid-up capital of all deposit-taking banks and establishment of discount houses for the conduct of OMO. The cash reserves requirements were raised from $2.0 \%$ to $6.0 \%$ and the liquidity ratio fixed at $25 \%$ since 1960 was revised upward to $30 \%$ in 1986 . The exchange rate and interest rate were liberalized to be determined by the forces of demand and supply.

The introduction of market-based approach came with it's challenges. There was a drastic increase in the number of banks and waves of banks distress. From fourty (40) in 1986, the number of banks increased to one hundred and twenty (120) in 1993 while bank's assets (total claims or lending to public and private sector) to GDP ratio was only $17 \%$, one of the lowest in the world. This stirred up intense competition among banks leading to greater risk-taking and consequently insolvency, increased wave of bank's distress and failures in the 1990's and early 2000's. Pat and James (2011) reported that the number of distressed banks were eight (8) in 1991, sixteen (16) in 1992, thirty-eight (38) in 1993, fifty five (55) in 1994 and sixty (60) in 1996. Also, Gunu (2009) reported that between 1994 and 2003 about thirty six (36) banks in the country were closed as a result of insolvency. Bassey (2012) report shows that in 1998 alone about twenty six (26) banks were closed due to insolvency. To curb bank distress, recapitalization and consolidation exercise had been carried out. The capital base of banks had been raised from $\$$ million in 1988 to $\$ 50$ million in 1991, $\$ 500$ million in 1998, 1 billion in 2001, $\$ 2$ billion in 2002, and $\$ 25$ billion in 2005 .

Monetary management during market-based regime has not been very successful in maintaining macroeconomic stability. The inflation rate, real interest rate and exchange rate deteriorated seriously. Table 1 shows selected macroeconomic policy variables and performance indicators. As shown in Table1, the exchange rate which was $\$ 2.02$ to US $\$ 1.00$ in 1986 maintained a downward trend to $\$ 84.00$ and $\$ 133.50$ to US\$1.00 in 1997 and 2004 respectively. The substantial depreciation in exchange rate is attributed to expansionary fiscal and monetary policies, import dependence for production and consumption, high rate of inflation, evasion and avoidance of import duty payment and unethical behavior of some authorized dealers (Fakiyesi, 1998). Due to persistent fiscal expansion and monetization of deficits, there was excessive growth in money supply in the economy which culminated to high rate of inflation. The growth rate of money supply, measured by the level of broad money $\left(\mathrm{M}_{2}\right)$, is provided in Table 1. Table 2 shows interest rates and inflation rates in Nigeria. As shown in Table 2, the inflation rate which was $5.4 \%$ in 1986 increased tremendously to $72.8 \%$ in 1995 , before moderating at $29.4 \%$ 1996. There was an upward increase of double digit inflation rate between 2002 and 2005. It increased from $12.9 \%$ in 2002 to $14.0 \%, 15.0 \%$ and $17.9 \%$ in 2003, 2004 and 2005 respectively. Between 
1970 and 2006, except for a few years (1982, 1985, 1986, 1990, 1997, 1999, 2000 and 2006), there have been double digits inflation rate in Nigeria.

Interest rate is another important macroeconomic variable through which monetary policy affects the economy. Interest rates affect savings, availability of credits, investment and economic growth. Four categories of interest rate are identified, namely, rediscount rates (rechristened monetary policy rate (MPR) by the Central Bank of Nigeria in 2006), rates on government securities, deposit and lending rates. MPR is the rate which the Central Bank of Nigeria (CBN) charges other banks on loans. This rate is fixed and varies by the apex bank according to the direction it desires other interest rates (and consequently money supply) in the economy to follow. Government securities rates, comprising treasury bills rate, treasury certificates rate and

Table 1: Nigeria: Selected Macroeconomic Policy Variables and Performance Indicators $(1970$ - 2005) (\%)

\begin{tabular}{|c|c|c|c|c|c|c|c|c|c|c|}
\hline Year & $\mathrm{Y}$ & I & I/GDP & $\mathrm{CrdPu}$ & $\mathrm{CrdPr}$ & Def/GDP & Dd/GDP & Ed/GDP & $\begin{array}{c}\text { EXCR } \\
\text { (\#) }\end{array}$ & M2 \\
\hline 1975 & 6.0 & 55.5 & 25.2 & - & - & 18.1 & - & - & 0.64 & 73.5 \\
\hline 1981 & -0.8 & 6.8 & 23.2 & 40.3 & 59.7 & 27.7 & 22.1 & 4.6 & 0.55 & 8.0 \\
\hline 1982 & -2.5 & -25.9 & 20.0 & 47.9 & 52.1 & 3.6 & 29.0 & 17.1 & 0.61 & 8.7 \\
\hline 1983 & -7.1 & -26.2 & 14.6 & 57.3 & 42.7 & 9.3 & 38.9 & 18.5 & 0.67 & 14.7 \\
\hline 1986 & 3.0 & 14.3 & 14.9 & 78.1 & 28.9 & 12.2 & 38.9 & 56.7 & 2.02 & 4.23 \\
\hline 1987 & -0.6 & -25.0 & 13.7 & 50.4 & 49.6 & 5.5 & 33.8 & 92.6 & 4.02 & 22.9 \\
\hline 1988 & 10.0 & -13.9 & 13.5 & 53.5 & 40.5 & 8.4 & 32.4 & 92.4 & 4.54 & 35.0 \\
\hline 1989 & 7.3 & 35.5 & 14.1 & 12.0 & 98.0 & 6.7 & 20.9 & 106.9 & 7.39 & 3.54 \\
\hline 1990 & 13.0 & 35.7 & 14.5 & 39.1 & 60.9 & 8.5 & 32.3 & 114.6 & 8.04 & 45.9 \\
\hline 1995 & 2.2 & 5.1 & 5.1 & 55.4 & 44.6 & 0.7 & 17.2 & 36.2 & 81.15 & 19.5 \\
\hline 1996 & 3.4 & -11.3 & 5.2 & 29.8 & 70.2 & 0.8 & 12.2 & 21.9 & 81.20 & 16.2 \\
\hline 1997 & 3.8 & -6.1 & 5.4 & 12.7 & 87.3 & -0.1 & 12.5 & 21.0 & 84.00 & 16.0 \\
\hline 1998 & 2.4 & -8.9 & 5.3 & 27.3 & 72.7 & -3.3 & 19.4 & 22.9 & 93.95 & 22.3 \\
\hline 1999 & 2.6 & 53.0 & 23.4 & 28.0 & 72.0 & -5.9 & 22.9 & 80.7 & 93.95 & 33.1 \\
\hline 2000 & 3.8 & 38.3 & 20.3 & -26.3 & 126.3 & -1.5 & 18.6 & 64.0 & 102.10 & 48.1 \\
\hline 2001 & 3.9 & 17.8 & 24.1 & -0.71 & 100.7 & 3.1 & 18.5 & 59.1 & 111.20 & 27.0 \\
\hline 2002 & 3.3 & -2.0 & 26.2 & 28.1 & 71.9 & 3.8 & 14.9 & 50.4 & 120.97 & 21.6 \\
\hline 2003 & 10.2 & 6.5 & 22.3 & 32.8 & 67.2 & 2.0 & 13.4 & 45.2 & 129.36 & 24.1 \\
\hline 2004 & 6.5 & 10.0 & 22.3 & 24.0 & 76.0 & 1.5 & 12.0 & 42.8 & 133.50 & 14.0 \\
\hline
\end{tabular}

Notes:

$\mathrm{Y}=$ GDP Growth Rate; I = Gross Investment Growth rate; I/GDP = Gross Investment/ GDP; $\mathrm{CrdPu}=$ Credits to Public Sector; $\mathrm{CrdPr}=$ Credits to Private Sector; Def/GDP = Overall Deficit/Surplus/GDP; Dd/GDP = Domestic Debt/GDP; Ed/GDP = External Debt/GDP; EXCR = Exchange Rate ( $\$$ / $\$$ ); $\mathrm{M}_{2}=$ Growth Rate of Broad Money Sources: (1) CBN's Statistical Bulletin (various issues) (2) CBN's: Annual Report and Statement of Accounts (various issues) (3) Author's Calculation.

government development stock rate, vary according to their maturity structures. Deposit rates are of two types savings and time deposit rates. Time deposit rate depends on the maturity of the deposit, which ranges from seven (7) days to twelve (12) months. Lending rates are of two types - the minimum (prime) and the maximum lending rates. An observable feature of interest rate in Nigeria reveals in Table 2 is that the lending rate to productive sector of the economy has been very high. Banks paid low savings deposit rate, borrowed from the Central Bank of Nigeria at low rate and lend out to the productive sector at a very high lending rate. For instance, in the year 1997, MPR was $13.54 \%$ and saving deposit rate was only $4.80 \%$ whereas the lending rate was $23.32 \%$. The low saving deposit rate does not encourage saving in the economy and the high lending rate inhibits borrowing for investment purposes.

It has been also observed that for most of the years, real interest rate were negative. Real interest rate is the interest rate which reflects borrowers and savers purchasing power whereas nominal interest rate is the interest rate received or paid by banks. Real interest rate is the difference between nominal interest rate and inflation rate while nominal interest rate is the sum of real interest rate and inflation rate. The negative real interest rates was as a result of high inflation rate prevalence in those years and is attributed to lack of proper coordination between fiscal and monetary policies, policy inconsistencies and historically inefficient 
management of the economy (Fakiyesi, 1996). The implication is that interest rate does not influence saving in Nigeria.

Public sector has, for a long time, played dominant role in the Nigerian economy while private sector existed just as an appendix. Even economic activities which traditionally fall within the domain of the private sector were undertaken by the public sector. Consequently, the fiscal operations of the government expanded outrageously. As government expenditure assumed an expansive stance coupled with dwindling revenue from the sale of crude oil, there was large fiscal deficit especially from 1983, which culminated in large public sector credits with bulk of the advances to the government to bridge the deficits gap coming from the banking system, while credits to the private sector dwindled. Hence, there was disproportionate allocation of credits in the economy in favour of public sector. As shown in Table1, between 1983 and 1995 (except in 1989, 1990 and 1991) credits to public sector were greater than that of the private sector. For instance, in 1986 and 1993 public sector received $78.1 \%$ and $66.0 \%$ respectively of the total credit to the economy. However, from 1996 and especially with the emergent of Civilian administration, credits to the economy trend change in favour of private sector. The private sector credits were $87.3 \%$ in 1997 and $126.3 \%, 100.7 \%$ and $92.12 \%$ in the year 2000 , 2001 and 2006 respectively. This is a good omen because increased private sector credits leads to increased economic activities which impact positively on key aggregates of the economy such as GDP, investment, employment, income, consumption and savings.

Table 2: Nigeria: Interest Rates and Inflation Rates (1970 - 2006) (\%)

\begin{tabular}{|c|c|c|c|c|c|c|c|c|}
\hline Year & $\begin{array}{l}\text { Minimum } \\
\text { Lending Rate (rd) }\end{array}$ & $\begin{array}{l}\text { Maximum } \\
\text { Lending Rate (R) }\end{array}$ & $\begin{array}{l}\text { Profit- } \\
\text { Seeking } \\
\text { (R-rd) }\end{array}$ & $\begin{array}{l}\text { Saving Deposit } \\
\text { Rate (S) }\end{array}$ & $\begin{array}{ll}\text { Saving/ } & \\
\text { Lending } & \text { Rate } \\
\text { Gap (R-S) } & \\
\end{array}$ & NIR & INFR & RIR \\
\hline 1970 & 7.0 & 8.0 & 1.0 & 3.0 & 5.0 & 8.0 & 13.8 & -6.3 \\
\hline 1975 & 6.0 & 9.0 & 3.0 & 4.0 & 5.0 & 9.0 & 33.9 & -24.9 \\
\hline 1980 & 7.50 & 9.50 & 2.0 & 6.0 & 3.50 & 9.5 & 9.9 & -0.4 \\
\hline 1981 & 7.75 & 10.0 & 2.25 & 6.0 & 4.0 & 10.0 & 20.0 & -10.9 \\
\hline 1982 & 10.25 & 11.75 & 1.50 & 7.50 & 4.25 & 11.8 & 7.7 & 4.1 \\
\hline 1983 & 10.0 & 11.50 & 1.50 & 7.50 & 4.0 & 11.5 & 23.2 & -11.7 \\
\hline 1984 & 12.50 & 13.00 & 0.50 & 9.50 & 3.50 & 13.0 & 39.6 & -26.6 \\
\hline 1985 & 9.25 & 11.75 & 2.50 & 9.50 & 2.25 & 11.8 & 5.5 & 6.3 \\
\hline 1986 & 10.50 & 12.00 & 1.50 & 9.50 & 2.50 & 12.0 & 5.4 & 6.6 \\
\hline 1987 & 17.50 & 19.20 & 1.70 & 14.00 & 5.20 & 19.2 & 10.2 & 9.0 \\
\hline 1988 & 16.50 & 17.60 & 1.10 & 14.50 & 3.10 & 17.6 & 38.3 & -20.7 \\
\hline 1989 & 26.80 & 24.60 & -2.20 & 16.40 & 8.20 & 24.6 & 40.9 & -16.3 \\
\hline 1990 & 25.50 & 27.70 & 2.20 & 18.80 & 8.90 & 27.7 & 7.5 & 13.2 \\
\hline 1991 & 20.01 & 20.80 & 0.79 & 14.29 & 6.51 & 20.8 & 13.0 & 7.8 \\
\hline 1992 & 29.80 & 31.20 & 1.40 & 16.10 & 15.10 & 31.2 & 44.5 & -13.5 \\
\hline 1993 & 18.32 & 36.09 & 17.77 & 16.66 & 19.43 & 18.3 & 57.2 & $\begin{array}{l}-38.8 \\
\end{array}$ \\
\hline 1994 & 21.00 & 21.00 & 0.00 & 13.50 & 7.50 & 21.0 & 57.0 & -36.0 \\
\hline 1995 & 20.18 & 20.79 & 0.61 & 12.61 & 8.18 & 20.8 & 72.8 & -52.0 \\
\hline 1996 & 19.74 & 20.86 & 1.12 & 11.69 & 9.17 & 20.9 & 29.4 & -8.44 \\
\hline 1997 & 13.54 & 23.32 & 9.78 & 4.80 & 18.52 & 20.9 & 8.5 & $\begin{array}{l}-12.4 \\
\end{array}$ \\
\hline 1998 & 18.29 & 21.34 & 3.05 & 5.49 & 15.85 & 21.8 & 10.0 & 11.0 \\
\hline 1999 & 21.32 & 27.19 & 5.87 & 5.33 & 21.86 & 27.2 & 6.6 & 20.6 \\
\hline 2000 & 17.98 & 21.55 & 3.55 & 5.29 & 16.26 & 30.0 & 6.9 & 23.1 \\
\hline 2001 & 18.29 & 21.34 & 3.05 & 5.49 & 15.85 & 24.0 & 18.9 & 5.1 \\
\hline 2002 & 24.85 & 30.19 & 5.34 & 4.15 & 26.04 & 24.0 & 20.2 & 3.8 \\
\hline 2003 & 20.71 & 22.88 & 2.17 & 4.11 & 18.77 & - & 14.0 & - \\
\hline 2004 & 19.18 & 20.82 & 1.64 & 4.19 & 16.63 & - & 15.0 & - \\
\hline 2005 & 17.95 & 19.43 & 1.48 & 3.83 & 15.60 & - & 17.9 & - \\
\hline 2006 & 16.89 & 18.41 & 1.52 & 3.13 & 15.28 & - & 8.2 & - \\
\hline
\end{tabular}

Sources: (1) CBN, Statistical Bulletin (various issues)

(2) CBN, Annual Report and Statement of Accounts (various issues)

(3) Authour's Calculation.

Fiscal Policy: A prudent fiscal policy is necessary for a stable macro-economy. Essentially, fiscal policy is meant for fine-tuning the economy to offset boom and depression during the course of business cycles. It encompasses government generation of revenue through variety of taxes on income (personal and corporate), 
goods and services; government spending, transfer, distribution of the costs and benefits of government spending and taxation and government policies on public sector enterprises (Bamidele and Englama, 1998). These affect the level, trend and efficiency of resources allocation, the fiscal position (surplus or deficit) and the macroeconomic aggregates such as aggregate demand, domestic price level, investment and the balance of payment position. The major instruments of fiscal policy have been taxation, government expenditure and borrowing (domestic and external) to finance deficit spending.

A noticeable feature of Nigeria's fiscal operations is that, over the years, both government revenue and expenditure had assumed increasing trend. In most of the years, government expenditure exceeded revenue resulting in deficit spending. From 1970 through 2003, except for 1995 and 1996, there had been deficit financing in Nigeria. Table 1 shows that the deficit/GDP ratio were $14.7 \%$ in 1970, 23.3\% in1980, $27.7 \%$ in 1981 and $15.3 \%$ in 1993. Between 1986 and 1993, the average deficit/GDP ratio was 9.3\%, which is by far in excess of the average deficit/GDP ratio target of 3.0\% expected during SAP period. Inferring from economic theory proposition of an inverse relationship between fiscal deficit and private investment, then it implies that Nigeria was not a fertile ground for private investment during those years. In addition, the deficit spending was not productively utilized on projects/programmes that are self sustaining or on the provision of infrastructure which are highly productive for the economy. Most of the infrastructural facilities had been either in a very bad state, in short supply or irregularly and inefficiently supplied. The result is economic environment which is unconducive for investment.

The deficit spending was financed from domestic and external borrowing, and draw-down on reserves. Most of the domestic deficit financing was from the banking sector, which accounted for as high as about 87.1\% in 1971 and $93.0 \%$ in 1975 of the total deficit financing. For periods, 1981 to 1990 and 1991 to 1998, the banking system accounted for an average of about $60.7 \%$ and $94.4 \%$ respectively of the total deficit financing. Deficit financing through banking system is unhealthy for the economy. First, it impacted negatively on monetary base, inflation rate and interest rate. Secondly, it had adverse effects on investment, productive capacity of the economy and economic growth as it reduces bank fund available for private sector borrowers, increases interest rate and the cost of fund for private investment. In addition, for most of the years, deficit financing was financed through Ways and Means of the Central Bank of Nigeria. This mode of deficit financing directly increases the monetary base and the level of excess liquidity in the economy which adversely affect exchange rate and price levels (Ojo, 2001).

There was unabated growth in public debt (both domestic and foreign debts). As shown in Table 1, the ratio of domestic debt stock to GDP was 35.5\% in 1993 and 40.4\% in 1995. As earlier stated, domestic debt leads to credit squeeze through higher interest rate and crowding-out effect on private sector investment as less banking system's credit becomes available for private sector's use. The external debt stock, on the other hand, rose from 3.7\% of GDP in 1988 to $14.6 \%$ of GDP and 36.2\% of GDP in 1990 and 1995 respectively despite the debt rescheduling and conversion efforts of the government. This had an excruciating effect on the balance of payment position by leading to a current account deficit, and appreciation of the real exchange rate with negative signals to foreign investors as well as seriously reducing available resources for domestic investment due to debt servicing burden. In effect, it led to "debt overhang" effect, crowding-out effect and credit rationing in Nigeria.

\section{Nigeria's Aggregate Investment and Economic Growth Rate (1970- 2006)}

Macroeconomic policies greatly affect investment and economic growth, though not directly but indirectly, through their effects on indicator variables such as volume of saving, interest rate (saving deposit and lending rates), inflation rate, exchange rate, credit to the economy (private and public), deficit financing and public debts analyzed above. As shown in Table 1, for most of the years covered by this study, gross investment growth rate were quite low and in some years negative. For example, in 1982, 1983 and 1984 the gross investment growth rate were $-25.9 \%,-26.2 \%$ and $-57.9 \%$ respectively. The volume of investment as a ratio of GDP in average was about $12.1 \%$ between 1986 and 1996. The average investment/GDP ratio of this period is lower than 13\% of GDP which Oshikoya (1994) prescribed as the minimum investment requirement for replacement of depreciated capital in Africa. From 1997 to 2005, investment /GDP ratio in average was 19,0\%. As earlier pointed out, the proportion of a country's GDP employ in investment strongly affects the rate growth of the economy. Low investment/GDP ratio is likely to result in low growth rate. As shown in Table 1, except for 1985, 1988, 1990 and 2000, GDP growth rates in Nigeria were low. In years like 1981, 1982, 1983, 1984 and 1987 , the growth rates of GDP were negative.

\section{Conclusion}

The paper examined the nexus of macroeconomic policy (monetary and fiscal policies), investment and economic growth in Nigeria. It has been established that monetary and fiscal policies significantly affect aggregate investment and economic growth in Nigeria. The monetary policy, up to 1986, was a non-market 
regime where key monetary aggregates were controlled through direct administratively control of monetary instruments. With the deregulation of the Nigerian economy and subsequent introduction of SAP, there was a shift to indirect monetary management through the use of market-based instruments. It is observed that though the CBN, within it's mandate, has make reasonable attempts to manage monetary policy, the macroeconomic stability objective which is crucial for raising the level of investment and promoting sustained economic growth is yet to be achieved. Except for few years, there have been double digits inflation rate, high interest and exchange rates. There was persistent fiscal expansion and monetization of deficits which fueled inflationary pressure in the economy. The exchange rate had depreciated substantially due to expansionary fiscal and monetary policies, import dependence for production and consumption, high rate of inflation, evasion and avoidance of import duty payment and unethical behavior of some banks. Implementation of monetary policy during market regime did not encourage saving and borrowing for investment purposes. Banks borrowed from the Central Bank of Nigeria at low interest rate, paid low saving deposit rate and lend out to the productive sector at a very high lending rate. The expansion of government fiscal operation resulted in huge deficit financing which was financed by both internal and external loans. The major internal source of financing the deficits was the banking system. This had adverse consequences on macroeconomic stability, investment and economic growth. The implementation of monetary and fiscal policies has been such that the actual monetary variables deviated significantly from targets, thereby produced excess liquidity in the economy with adverse consequences on inflation rate, exchange rate, etc.

\section{Recommendations}

It is the conviction of the author that a stable macro-economy with appropriate rate of investment and sustained growth can be achieved through a prudent and effective managed macroeconomic policy. On this note, the following recommendations are made. There should be effective coordination of monetary and fiscal policies in the country. The monetary and fiscal authorities should work together and ensure that monetary and fiscal policies are properly harmonized. To encourage saving and investment in the economy, CBN should strongly discourage exploitative tendencies of banks (paying low saving deposit rate, borrowing from CBN at low interest rate and lending out to productive sector at a very high lending rate) and monetary policy should focus on lowering interest rate and increasing the availability of credits, especially, to the productive sector of the economy. The monetary authority should strive and maintain one digit inflation rate in the country. A single digit inflation rate is needful as it is conducive for macroeconomic stability and will enable real investors to make long term plan, reliable projection of industrial capacities, market potentials, future profits and return on investment. The effectiveness of macroeconomic policy, especially monetary policy, depend to a great extend on the relative degree of CBN independence, the health of the banking system, social and political stability of the country. The autonomy of the CBN should not for any reason be compromised. The banks should effectively carry out their financial intermediation role, avoid sharp and unscrupulous practices and discipline themselves to play according to the rules of the game. Those charged with the responsibility of managing Nigerian economy should ensure that there is transparency, honesty, prudence, and accountability in the conduct of fiscal operations. Mismanagement of public resources and corruption should be avoided. The current fight against corruption in the country should be intensified. There should be good governance. Democratic government should be sustained in the country. The Nigerian exports should be diversified. Since independence, Nigeria's external trade has been dominated by primary product (crude oil and agricultural commodities). With the deregulation of the economy, it is pertinent to prioritize production for export of manufactured products especially high technology products and services. There should be adequate, reliable and efficient infrastructure in the country since infrastructure plays prominent role in promoting investment by lowering the cost of production and increasing the profitability. The government should as matter of urgency revitalizes the deplorable state of the nation's networks of roads, provides adequate and reliable electricity supply, and adequate treated water supply for human consumption and economic activities.

\section{References}

[1]. Agu, C. C. (1988). Interest Rates Policy in Nigeria and Its Attendant Distortions. Savings and Development. XII (1): 19-33.

[2]. Ahuja, H. L. (2011). Macroeconomics: Theory and Policy, Nagar, New Delhi, S. Chand \& Company Ltd.

[3]. Aschauer, D. A. (1989). Is Public Expenditure Productive? Journal of Monetary Economics, 23:177-200.

[4]. Bamidele, A. and A. Englama (1998). Macroeconomic Environment, Investment stimulation and Economic Growth and Development: The Nigerian Experience. In: Ben A. Aigbohkan, ed. Rekindling Investment for Economic Development in Nigeria. The Nigerian Economic Society, Ibadan, pp.129-143.

[5]. Bassey, G. E. (2012). The Impact of Recapitalization and Consolidation on Bank Performance in Nigeria. International Journal of African Culture, Politics and Development, 7(2): 1-16, September.

[6]. Central Bank of Nigeria Statistical Bulletin (Various Issues).

[7]. Central Bank of Nigeria Annual Report and Statement of Accounts, (Various Issues).

[8]. Dailamu, M. and M. Watson (1989). Private investment, Government Policy and Foreign Capital in Zimbabwe, Pre - Working Paper 409, World Bank. Processed.

[9]. Dornbusch, R. and S. Fischer (1981). Macroeconomics, Tokyo, Japan, McGraw-Hill Inc. 
[10]. Easterly, W. and K. Schmidt-Hebbel (1993). Fiscal Deficits and Macroeconomic Performance in Developing Countries. The World Bank Research Observer, .8(2): 211-238, July.

[11]. Ekpo, A. H. (2003). Economic crisis and the challenge of Macroeconomic Management in Nigeria. Paper presented at the Debt Management Officer (DMO) Guest Speaker Forum, October, 24, Abuja.

[12]. Ekpo, U. N. and Adaowo, M. A. (2011). Deficit Financing: How Relevant in National Economic Management? The International Journal Series on Tropical Issue, (August). Deemis, Douala, 12(2): 60-78

[13]. Ekpo, U. N. (2011). Public Investment and Infrastructural Development: The case of Electric Power Supply in Nigeria (1970-2004), An Unpublished Ph.D. Thesis, Department of Economics, University of Uyo, Uyo, Nigeria.

[14]. Fakiyesi, T. (1996). Interest Rate Policy Management in Nigeria : An Overview. In Ariyo, A. ed. Economic Reform and Macroeconomic Management in Nigeria. The Centre for Public-Private Cooperation, Ibadan

[15]. Fakiyesi, O. M. (1998). The Performance of the Nigeria Financial Sector since 1986. In: Ben A. Aigbohkan, ed. Rekindling Investment for Economic Development in Nigeria. The Nigerian Economic Society, Ibadan, pp.127-144.

[16]. Fisher, S. (1991) Macroeconomic Development and Growth, NBER Macroeconomic Annual, pp.329-364.

[17]. Green, J. and D. Villanuera (1991) Private Investment in Developing Countries, An Empirical Analysis, IMF Staff Paper, .38(1): 33-38.

[18]. Gunu, U. (2009). The Impact of Banking system Recapitalization on Employment in Nigeria. Journal of Social Sciences. 11(3):486495 .

[19]. Hadjimichael, M. D. et al (1995), Growth, Savings and Investment (1986-1993), New York, International Monetary Fund.

[20]. Iyoha, M. A. (1998). Rekindling Investment for Economic Development in Nigeria; The Macroeconomic Issues. In Ben. A. Aigbohkan, ed. Rekindling Investment for Economic Development in Nigeria, The Nigerian Economic Society, Ibadan, pp.35-58.

[21]. Iyoha, M. A. (1997). Policy Simulation with a Model of External Debt and Economic Growth in Sub Saharan African Countries. Nigerian Economic and Financial Review. Vol. 2, December.

[22]. Jerome, A. (1999). Infrastructure in Africa: The Record. Economic Research Paper, No.46, African Development Bank, Abidjan

[23]. Jhingan, M.L. (2010). Macroeconomics Theory, Vrinda Publication (P) Ltd, Mayur Vihar, Delhi.

[24]. Kindleberger, C. P. (1965). Economic Development. New York, McGraw Hill.

[25]. Lucas, R. (1988). On the Mechanics of Economic Development. Journal of Monetary Economics, 22:3-42.

[26]. Mckinnon, R. I., 1973. Money and Capital in Economic Development. 1st ed., Washington D.C., USA. Brookings Institution.

[27]. Nnanna, O. J. (2002). Monetary Policy and Exchange Rate Stability in Nigeria.. Proceedings of a one-day seminar on Monetary Policy and Exchange Rate Stability held on $23^{\text {rd }}$ May, 2002. The Nigerian Economic Society, Ibadan.

[28]. Obaseki, P. J. and E. A. Onwioduokit (1998). Public and Private Investment and Economic Growth: Investment for Economic Development in Nigeria. In: Ben A. Aighokham, ed. Rekindling Investment for Economic development in Nigeria. The Nigerian Economic Society, Ibadan, pp. 365-381.

[29]. Ojo, M. O. (2001). Principles and Practices of Monetary management in Nigeria, CBN. Part 11,Chapter 11-15

[30]. Oresetu, O. (1993). Implementation of indirect Monetary Control in Nigeria: Problems and Prospects. Economic and Financial Review, CBN, 31(3), September.

[31]. Oshikoya, T. W. (1994). Macroeconomic Determinants of Domestic Private Investment in Africa: An Empirical Analysis. Economic Development and Cultural Change, 42(3).

[32]. Oshikoya, T. W. and Hussian, M. (2002). Infrastructure for Economic development in Regional Integration in Africa. Paris: OCED Publication.

[33]. Oyejide, T. (2002). Monetary Policy and It's Effects on the Nigerian Economy. Proceedings of a one-day seminar on Monetary Policy and Exchange Rate Stability, held on $23^{\text {rd }}$ May, 2002. The Nigerian Economic Society, Ibadan.

[34]. Pat, D. and James, O. (20011). Effects of the consolation of the Banking Industry on the Nigerian Capital Market. Journal of Economics, 2(1): 57-65.

Peterson, W. C. (1978), Income, Employment and Economic Growth, New York, Norton and Company Inc., Fourth Edition.

[36]. Romer, P. M. (1990). Human Capital and Growth: Theory and Evidence. Carnegie-Rochester Conference Series on Public Policy, $40,47-57$

[37]. Sanusi, J. O. (2001). The Nigerian Economy: Growth Productivity and the Role of Monetary Policy. Development Policy Centre. Annual Lecture 2001. DPC. Ibadan.

[38]. Scott, M. (1991), A new view of Economic Growth; Four Lectures. World Bank Discussion Paper, 131, Washington D.C., The World Bank.

[39]. Soludo, C. C. (1998). Investment in the Growth Process: A Measure of the Economists' ignorance in Africa. In: Ben A. Aigbhkan, ed. Rekindling Investment for Economic Development in Nigeria, The Nigerian Economic Society, Ibadan, pp. 1-33.

[40]. Stightz, J. E. (1996). Some Lessons from the East Assian Miracles. The World Bank Research Observer (August), $11(2): 151$ - 177.

[41]. Yolopoulost, P. A. and J. B. Nugent (1976), Economics of Development: Empirical Investigations, New York, Harper and Row Publishers. 